\title{
Altitudinal Effect on Diversity and Distribution of Araceae in Doi Suthep-Pui National Park, Chiang Mai Province in Thailand
}

\author{
Oraphan Sungkajanttranon ${ }^{1}$, Dokrak Marod ${ }^{2}$, Sahanat Petchsri ${ }^{1}$, Kritsiam Kongsatree ${ }^{3}$, Anothai Peankonchong ${ }^{3}$, \\ Thunthicha Chotpiseksit ${ }^{1}$ and Benjawan Supnuam ${ }^{1}$ \\ 1. Faculty of Liberal Arts and Science, Kasetsart University, Kamphaeng Saen Campus, Nakhon Pathom 73140, Thailand \\ 2. Faculty of Forestry, Kasetsart University, Chatuchak, Bangkok 10900, Thailand \\ 3. Protected Area Regional Office 16, Mueang, Chiang Mai, 50000, Thailand
}

\begin{abstract}
The relationships between Araceae diversity and altitude gradients in mountain ecosystem at Doi Suthep-Pui National Park, Chiang Mai Province in Thailand, were studied during January 2016-March 2018. The strip-plots, $10 \mathrm{~m} \times 1,000 \mathrm{~m}$ along the five nature trails, were established from 300-500, 501-800, 801-1,100, 1,101-1,400, 1,401-1,685 m above mean sea level (amsl). Twenty species of 11 genera were found. Alocasia navicularis and Lemna sp. were found at 300-500 m amsl, wild taro (Colocasia esculenta) was at 300-800 m amsl, A. acuminata was at 300-1,400 m amsl, while Amorphophallus krausei, Hapaline benthamiana, Lasia spinosa, Rhaphidophora chevalieri and R. megaphylla were at 501-800 m amsl, but dwarf taro (C. affinis) was at 501-1,400 m amsl, Homalomena aromatica was at 801-1,100 m amsl, A. fuscus, A. thaiensis were at 801-1,685 m amsl, A. yunnanensis was at 1,101-1,685 m amsl, only five species, Arisaema consanguineum, A. kerrii, Remusatia hookeriana, R. peepla and Sauromatum horsfieldii were found at 1,401-1,685 m amsl. Species diversity in the rainy season was the highest (1.75), the top five dominant species were dwarf taro (C. affinis), wild taro (C. esculenta), A. fuscus, A. acuminata and A. thaiensis (importance value index (IVI\%): $61.54,24.13,17.12,16.52$ and 9.60 , respectively). In dry season, the dominant species was wild taro. The altitude gradients showed the main effect on diversity and distribution of Araceae.
\end{abstract}

Key words: Araceae, altitude gradients, Doi Suthep-Pui National Park, mountain ecosystem.

\section{Introduction}

Araceae in Thailand has been used for food, medicinal herb and ornamental plant for a long time [1, 2]. Many species are the native plants or endemic species, while many species are the exotic [3]. Araceae all over Thailand was recorded 26 genera 209 species in the journal Flora of Thailand, volume 11, part two: Acoraceae and Araceae [4] and almost 70 species in Northern Thailand were published. In Thailand, plant species have been surveyed and reported since 1922 [5], but the database of specific area and species do still not

Corresponding author: Oraphan Sungkajanttranon, assistant professor, research fields: environmental impacts of agriculture and forestry. cover the protected areas and natural areas. This family is not in the three appendices of classification and permit requirements of Thailand by the Convention on International Trade in Endangered Species (CITES) [6]. Local people can collect all parts easily for cooking food, making herbal medicine, decorating house and selling vegetation to the ornamental markets both inside and outside Thailand [7].

The wide protected area, national park is like the museum of living plant specimens, because it has many forest types and high biodiversity of flora and fauna. In 2008-2012, Araceae species were studied in the national parks of Kanchanaburi Province [8-12]. Doi Inthanon National Park, one of the most famous protected areas in Chiang Mai Province, the highest 
mountaintop of Thailand, was surveyed for recording growth and distribution of Araceae between 2014 and 2016 [13]. Twenty three species were found from 300-2,565 m above mean sea level (amsl). The study of Araceae species had less data, then was interested to record more data at Doi Suthep-Pui National Park $\left(18^{\circ} 42^{\prime} \mathrm{N}-19^{\circ} 07^{\prime} \mathrm{N}, 98^{\circ} 45^{\prime}\right.$ E-98 $57^{\circ}$ E), Chiang Mai Province, Northern Thailand (Fig. 1), the area is 261.06 $\mathrm{km}^{2}$ [14]. Many researchers found many species of plants, animals, microorganisms and also reported about plant ecology, plant community and ethnobotany in this area $[15,16]$, but had less database about Araceae ecology [5]. The local people cannot collect species in the national park, but they can collect or keep out many species from agricultural area or natural area outside the protected area which had no permit from the government. Then, Araceae richness should be higher in the national park than the other areas. The very high mountain ranges in Chiang Mai and other nearby are a part of Himalaya Mountains, the unique mountain ecosystems in Northern Thailand [14], and should be sustainably conserved for biodiversity and community services [17]. Thus, Doi Suthep and Doi Pui in this national park were also suitable and aimed to study about the altitudinal effect and compared diversity and distribution of Araceae to Doi Inthanon National Park which are in the different part of Thanon Thong Chai Range [13].

In addition, Doi Suthep-Pui is one of the most famous national parks in Thailand, because of the location in the city, comfortable temperature, good scene mountains view, green forests, wonderful and strange vegetation, graceful waterfalls, beautiful and charming palace, many government offices, peaceful villages and temples of local people [14, 18]. Nevertheless, the very good highway, the taking care of the tourist police and the authority of the national park can promote the tourist to visit here. The tourists are favorite to cyclinging, biking and driving from Chiang Mai city to tourist attractions along the highway to the famous temple, Wat Phra Tat Doi Suthep until to Doi
Pui summit for hiking and camping or walking along the nature trails to visit the waterfalls all year. Thus, terrestrial plants like Araceae can be harmed easily and the status of most species in Thailand are still at least concern by the category of the International Union for Conservation of Nature and Natural Resources (IUCN), in the IUCN Red List of Threated Species [19].

From these reasons, this study needed to know about the altitudinal effect on diversity and distribution of Araceae in this mountain ecosystem. The environmental effect and ecological service to the local people or tourist are threat to this family or have no effect from these problems. The results must record the database and be applied to plan sustainable conservation of plant resources in this protected area and the other national parks in the future.

\section{Materials and Methods}

The study area is in Doi Suthep-Pui National Park, locates in the west of Chiang Mai Province in Thailand. The head office location is at $18^{\circ} 48^{\prime} 34^{\prime \prime} \mathrm{N}$, $98^{\circ} 54^{\prime} 57^{\prime \prime} \mathrm{E}$ and covers $261.06 \mathrm{~km}^{2}$ in Mueng district and Mae Rim district (Fig. 1). Average rainfall is 1,350-2,500 $\mathrm{mm}$ per year, it rains average $139 \mathrm{~d}$ per year. Average temperature is $20-23{ }^{\circ} \mathrm{C}$ and lowest temperature is $6{ }^{\circ} \mathrm{C}$ in the winter. Average of relative humidity is $70 \%-80 \%$ all year. The study sites were surveyed for planning from January to December 2016 [20] and recorded data from March 2017 to March 2018.

\subsection{Study Site}

The strip plots, $10 \mathrm{~m} \times 1,000 \mathrm{~m}$ were established in every $300 \mathrm{~m}$ amsl, from $300-1,685 \mathrm{~m}$ amsl, along the five nature trails (Fig. 1). Zone 1 started at $18^{\circ} 48^{\prime} 42^{\prime \prime}$ $\mathrm{N}, 98^{\circ} 56^{\prime} 40^{\prime \prime}$ E, 300-500 m amsl along Huey Kaew Waterfall nature trail. Zone 2 started at $18^{\circ} 49^{\prime} 01^{\prime \prime} \mathrm{N}$, 98 55'33" E, 501-800 m amsl along Montha Tharn Waterfall nature trail. Zone 3 started at $18^{\circ} 48^{\prime} 33^{\prime \prime} \mathrm{N}$, 98 $54^{\prime} 55^{\prime \prime}$ E, 801-1,100 m amsl along Sai Thong Waterfall nature trail. Zone 4 started at $18^{\circ} 48^{\prime} 25^{\prime \prime} \mathrm{N}$, 
98 $54^{\prime} 35^{\prime \prime}$ E, 1,101-1,400 m amsl along Huey Khok Mah nature trail. Zone 5 started at $18^{\circ} 49^{\prime} 22^{\prime \prime} \mathrm{N}$, 98 53'36" E, 1,401-1,685 m amsl along Doi Pui Summit nature trail.

Forest type at the elevation below $1,000 \mathrm{~m}$ amsl is deciduous dipterocarp forest and dry evergreen forest, and the forest type above $1,000 \mathrm{~m}$ amsl is lower montane forest. Common trees in deciduous forest and evergreen forest were in family Dipterocarpaceae, Fagaceae and Magnoliaceae. Zone 1 was in deciduous dipterocarp forest, soil type was sandy soil, pale brown, well drainage and less organic matter. Zones 2 and 3 were in dry evergreen forest, soil type is sandy loam soil, reddish brown, thin layer of litter on the surface soil, the plot along the stream had soil moisture content all year. Zones 4 and 5 were in lower montane forest. Soil type of zone 4 was sandy loam soil, but zone 5 has high relative humidity and is also called "could forest", soil type, loamy sand, dark brown, thick layer of litter on the surface soil.

Zones 1, 2 and 3 are always tramped by many visitors all year because of the nature trails go to the famous attractions, but zones 4 and 5 are disturbed only in the winter and the summer with less number of visitors.

\subsection{Data Collection}

Monitoring was taken four times, in March, June, November 2017 and February 2018. Each strip plot was divided to 100 plots, $10 \mathrm{~m} \times 10 \mathrm{~m}$ for collection of data. Only native and endemic species were identified and photographs were taken by digital camera. Crop species were especially classified out of this study by using Araceae text books, Flora of Thailand (journal), Flora of China (journal), Kew, the Royal Botanic Gardens website and the International Aroid Society website. The data of individual numbers, forest types and environmental changing in all seasons were recorded. Species specimen were collected and dried to preserve at the Forest Herbarium, Department of National Park, Wildlife and Plant Conservation, Bangkok, Thailand.

\subsection{Data Analysis Method}

Species diversity of Araceae in each zone was analyzed based on the Shannon Wiener index, $H^{\prime}$ at the first equation [21]:

$$
\underset{\substack{S \\ i=1}}{H^{\prime}}=-\sum p i \ln p i
$$

where, $H^{\prime}=$ the Shannon index; $S=$ number of species; $p i=$ the proportion of individuals or abundance of the $i^{\text {th }}$ species; $\ln =\log$ base $e$.

The importance value index (IVI\%) was used to evaluate the dominant species in the area and was calculated as the sum of the relative density and relative frequency [22]. A species with a higher IVI\% value has greater dominance of the site [23].

\section{Results and Discussion}

\subsection{Diversity and Distribution}

Twenty species in 11 genera at Doi Suthep-Pui National Park were identified (Table 1 and Fig. 2). The

Table 1 Araceae species in Doi Suthep-Pui National Park at elevation 300-1,685 m above mean sea level (amsl), and IVI\%

\begin{tabular}{|c|c|c|c|c|c|c|c|c|}
\hline & Species & $\begin{array}{l}\text { Elevation } \\
(\mathrm{m} \text { amsl })\end{array}$ & Habit & Life form & Habitat & $\begin{array}{l}\mathrm{RD} \\
(\%)\end{array}$ & $\begin{array}{l}\mathrm{RF} \\
(\%)\end{array}$ & $\begin{array}{l}\text { IVI } \\
(\%)\end{array}$ \\
\hline 1 & Alocasia acuminata Schott & $300-1,400$ & $\mathrm{E}$ & Geo & LMF & 4.02 & 12.5 & 16.52 \\
\hline 2 & $\begin{array}{l}\text { A. navicularis (K.Koch \& C.D.Bouché) } \\
\text { K.Koch \& C.D.Bouché }\end{array}$ & $300-500$ & $\mathrm{E}$ & Geo & DDF & 0.38 & 3.12 & 3.50 \\
\hline 3 & Amorphophallus fuscus Hett. & $801-1,685$ & $\mathrm{D}$ & Geo & LMF & 4.62 & 12.50 & 17.12 \\
\hline 4 & A. krausei Engl. & $501-800$ & $\mathrm{D}$ & Geo & DEF & 0.15 & 3.12 & 3.27 \\
\hline 5 & A. thaiensis (S.Y.Hu) Hett. & $801-1,685$ & $\mathrm{D}$ & Geo & LMF & 0.21 & 9.39 & 9.60 \\
\hline 6 & A. yunnanensis Engl. & $1,101-1,685$ & $\mathrm{D}$ & Geo & LMF & 1.71 & 6.26 & 7.97 \\
\hline
\end{tabular}
in June 2017. 
(Table 1 continued)

\begin{tabular}{lllllllll}
\hline & Species & $\begin{array}{l}\text { Elevation } \\
(\mathrm{m} \mathrm{amsl})\end{array}$ & Habit & Life form & Habitat & $\begin{array}{l}\text { RD } \\
(\%)\end{array}$ & $\begin{array}{l}\text { RF } \\
(\%)\end{array}$ & $\begin{array}{l}\text { IVI } \\
(\%)\end{array}$ \\
\hline 7 & Arisaema consanguineum Schott & $1,401-1,685$ & $\mathrm{D}$ & Geo & LMF & 2.24 & 3.12 & 5.36 \\
8 & A. kerrii Craib & $1,401-1,685$ & $\mathrm{D}$ & Geo & LMF & 5.36 & 3.12 & 8.48 \\
9 & A. maxwellii Hett. \& Gusman & $501-1,100$ & $\mathrm{D}$ & Geo & DEF, LMF & 1.64 & 6.26 & 7.90 \\
10 & Colocasia affinis Schott & $501-1,400$ & $\mathrm{D}$ & Geo & DEF, LMF & 52.15 & 9.39 & 61.54 \\
11 & C. esculenta (L.) Schott & $300-800$ & E & Helo & DDF & 17.87 & 6.26 & 24.13 \\
12 & Hapaline benthamiana Schott & $501-800$ & D & Geo & DEF & 2.23 & 3.12 & 5.35 \\
13 & Homalomena aromatica (Spreng.) Schott & $801-1,100$ & E & Geo/Litho LMF & 0.45 & 3.12 & 3.57 \\
14 & Lasia spinosa (L.) Thwaites & $501-800$ & E & Helo & DEF & 0.22 & 3.12 & 3.34 \\
15 & Lemna sp. & $300-500$ & E & Hydro & DDF & 0 & 0 & 0 \\
16 & Remusatia hookeriana Schott & $1,401-1,685$ & D & Epi & LMF & 1.50 & 3.12 & 4.62 \\
17 & Rhaphidophora chevalieri Gagnep. & $501-800$ & E & Epi/Litho & DEF & 0.53 & 3.12 & 3.65 \\
18 & R. megaphylla H.Li & $501-800$ & E & Epi/Litho & DEF & 0.76 & 3.12 & 3.88 \\
19 & R. peepla (Roxb.) Schott & $1,401-1,685$ & E & Epi/Litho & LMF & 1.72 & 3.12 & 4.84 \\
20 & Sauromatum horsfieldii Miq. & $1,401-1,685$ & D & Geo & LMF & 2.24 & 3.12 & 5.36 \\
\hline & & & & & Total & 100 & 100 & 200 \\
\hline
\end{tabular}

$\mathrm{D}=$ deciduous, $\mathrm{E}=$ evergreen, $\mathrm{Epi}=$ epiphyte, $\mathrm{Geo}=$ geophyte, Helo = helophyte, Hydro = hydrophyte, Litho $=$ lithophyte, $\mathrm{DDF}=$ deciduous dipterocarp forest, $\mathrm{DEF}=$ dry evergreen forest, $\mathrm{LMF}=$ lower montane forest, $\mathrm{RD}=$ relative density, $\mathrm{RF}=$ relative frequency.
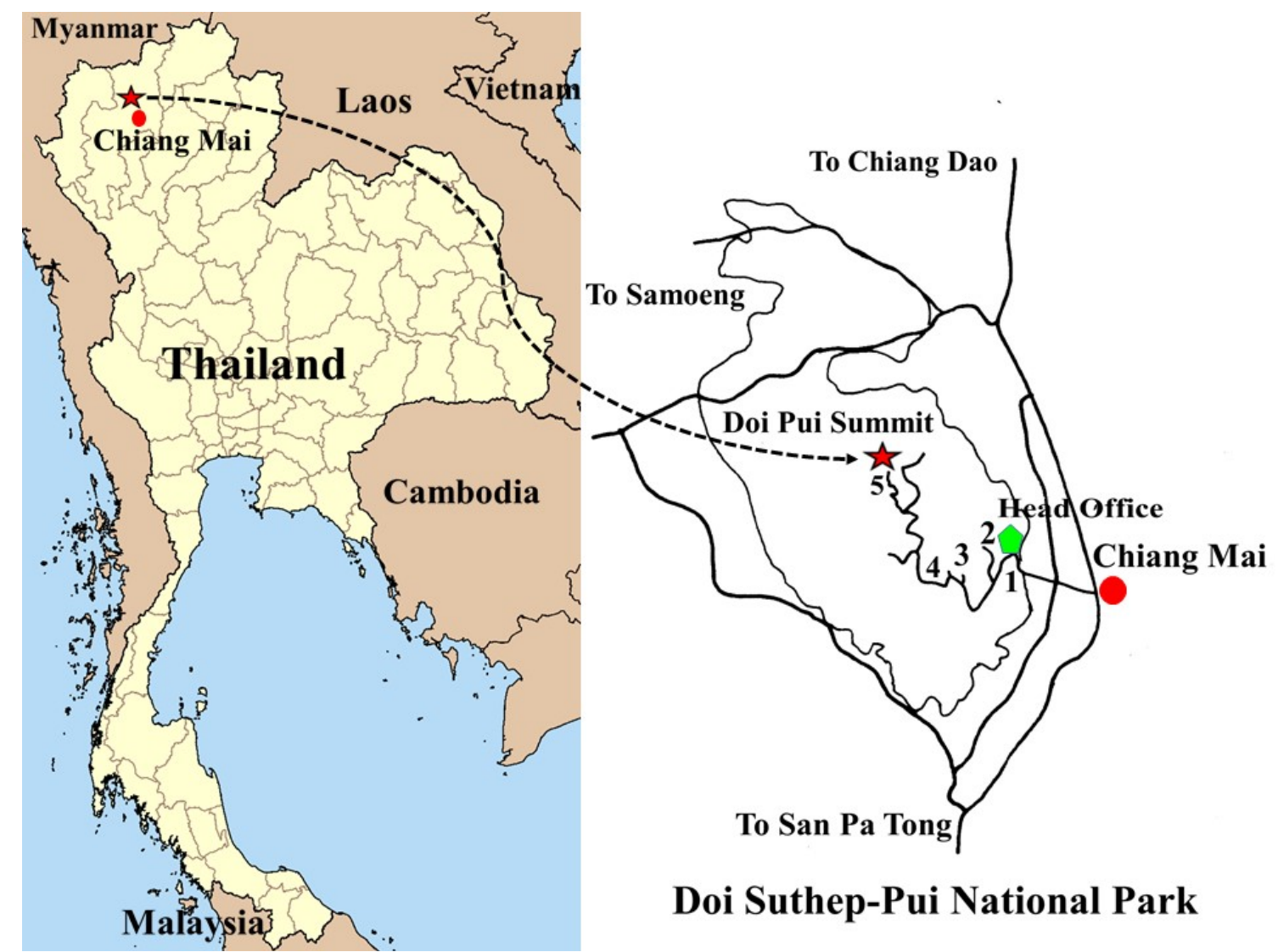

\section{Doi Suthep-Pui National Park}

Fig. 1 Five zones (1-5) at 300-1,685 m above mean sea level (amsl), in this study at Doi Suthep-Pui National Park in Chiang Mai Province, Northern Thailand.

Head office states at $18^{\circ} 48^{\prime} 34^{\prime \prime}$ N, 98 $54^{\prime} 57^{\prime \prime}$ E. Zone 1-5 started at 300-1,685 m amsl along five nature trails: Huey Kaew Waterfall, Montha Tharn Waterfall, Sai Thong Waterfall, Huey Khok Mah and Doi Pui Summit [14, 25]. 


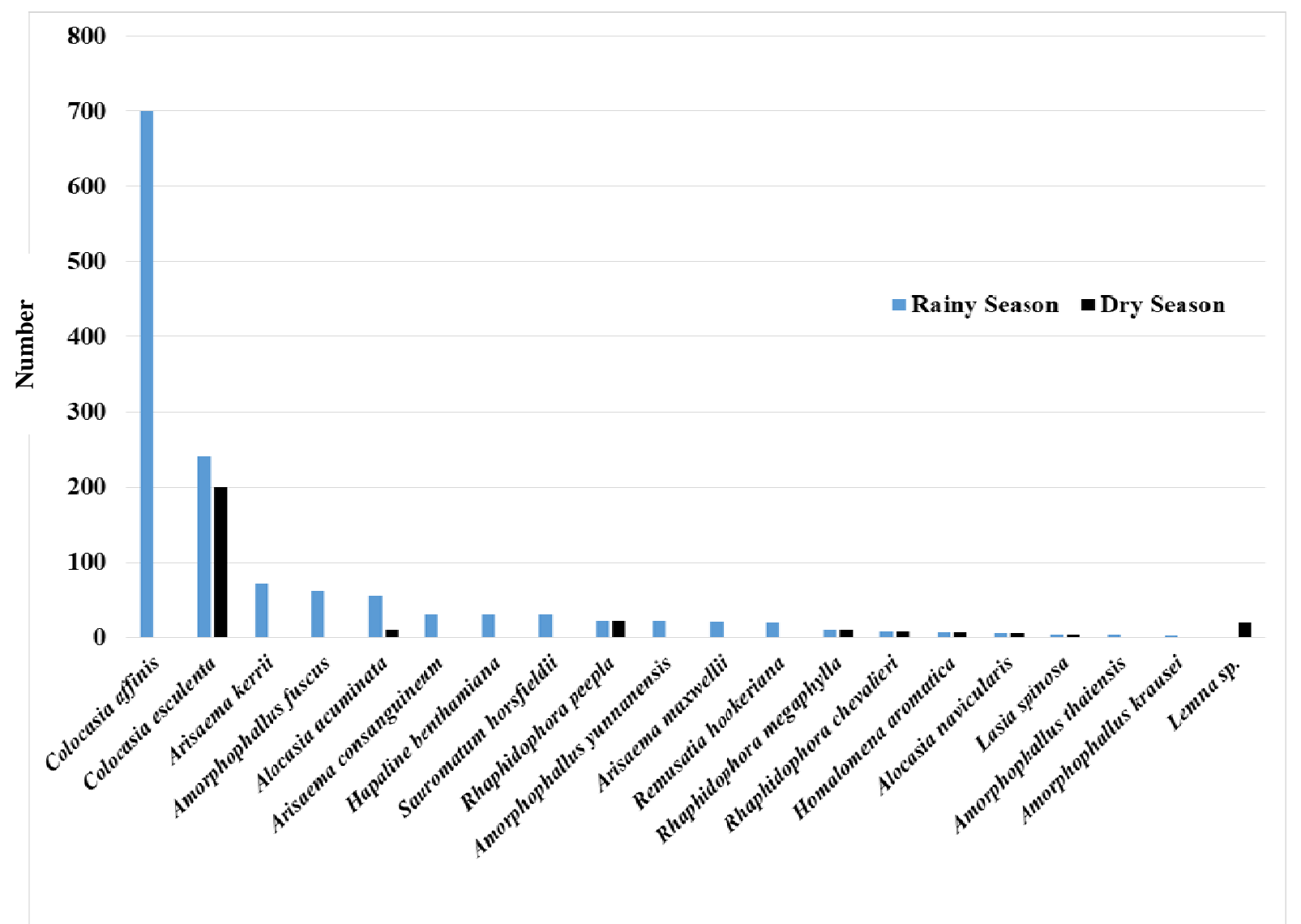

Fig. 2 Number of individuals by rainy season and dry season for the 20 Araceae species.

habits were classified to two groups, deciduous or evergreen, based on having a dormancy stage in winter and summer or growing all year [24]. The deciduous species were found 11 species in six genera: Amorphophallus fuscus Hett., A. krausei Engl., A. thaiensis (S.Y.Hu) Hett., A. yunnanensis Engl., Arisaema consanguineum Schott, A. kerrii Craib, A. maxwellii Hett. \& Gusman, dwarf taro (Colocasia affinis Schott), Hapaline benthamiana Schott, Remusatia hookeriana Schott and Sauromatum horsfieldii Miq. The other nine species in six genera were evergreen: Alocasia acuminata Schott, A. navicularis (K.Koch \& C.D.Bouché) K.Koch \& C.D.Bouché, wild taro (C. esculenta (L.) Schott), Homalomena aromatica (Spreng.) Schott, Lasia spinosa (L.) Thwaites, Lemna sp., Rhaphidophora chevalieri Gagnep., R. megaphylla H.Li and R. peepla (Roxb.) Schott.

Life forms (Table 1) of most deciduous species were considered to be geophyte, grown in the soil, except $R$. hookeriana, epiphyte/geophyte, grew both on oak (Castanopsis) trees and in the soil. The other nine evergreen species were considered to be hydrophyte (Lemna), helophyte (Colocasia and Lasia), geophyte (Alocasia), geophyte/lithophyte (Homalomena) and three species of Rhaphidophora were epiphyte/lithophyte [4, 24].

Species diversity in the rainy season (June, 2017) was highest (1.75), while in the summer and winter was lower (0.29 in March 2017, 1.17 in November 2017, 0.80 in February 2018). Variation in species and individual numbers was detected $(p<0.01$ and $p<$ 0.05 , respectively) and compared in the rainy season to the dry season (Fig. 2).

The IVI\% in June 2017 showed dominance species. The highest top five values were C. affinis (61.54\%), C. esculenta (24.13\%), A. fuscus (17.12\%), A. acuminata (16.52\%) and A. thaiensis (9.60\%), 
respectively (Table 2). In the dry season, winter and summer, only nine evergreen species were found. The first dominance species was C. esculenta $(88.60 \%)$, second was A. acuminata $(21.70 \%)$ and $R$. peepla $(17.19 \%)$ was the third.

Araceae abundance and distribution were related to the altitude and forest type (Table 1 and Fig. 3). The highest diversity was at 500-800 $\mathrm{m}$ amsl, nine species were found in dry evergreen forest along the waterfall: A. acuminata, A. krausei, A. maxwellii, dwarf taro ( $C$. affinis), wild taro (C. esculenta), H. benthamiana, $L$. spinosa, $R$. chevalieri and R. megaphylla. In the dry season, four species disappear because tubers were dormant in the soil and emerged again in the rainy season: A. krausei, A. maxwellii, C. affinis and $H$. benthamiana, while A. acuminata grew well in the soil, $R$. chevalieri and $R$. megaphylla climbed well on tree or limestone, wild taro and L. spinosa grew well nearby the waterfall.

In lower montane forest, subtype cloud forest, at
1,400-1,685 m amsl, eight species were distributed nearby the summit of Doi Pui, the highest peak of this national park: A. fuscus, A. thaiensis, A. yunnanensis, A. consanguineum, A. kerrii, $R$. hookeriana, $R$. peepla and $S$. horsfieldii. Most species disappear in the winter and summer, except $R$. peepla still climbing on trunks and branches of oak (Castanopsis) trees or on limestone. The temperature in this area was lower than the other study plots because of the lapse rate temperature by altitude level, liked at Doi Inthanon National Park whose temperature is decreased by 0.69 ${ }^{\circ} \mathrm{C}$ per $100 \mathrm{~m}$ amsl of higher elevation [26].

At 800-1,100 m amsl, six species were found in dry evergreen forest: A. acuminata, A. fuscus, A. thaiensis, A. maxwellii, C. affinis and $H$. aromatica. Individual number of six species was less than other zones, because the soil was dry and had no basin or waterfall nearby, only two species: $A$. acuminata and $H$. aromatica were evergreen, but the other six were deciduous.

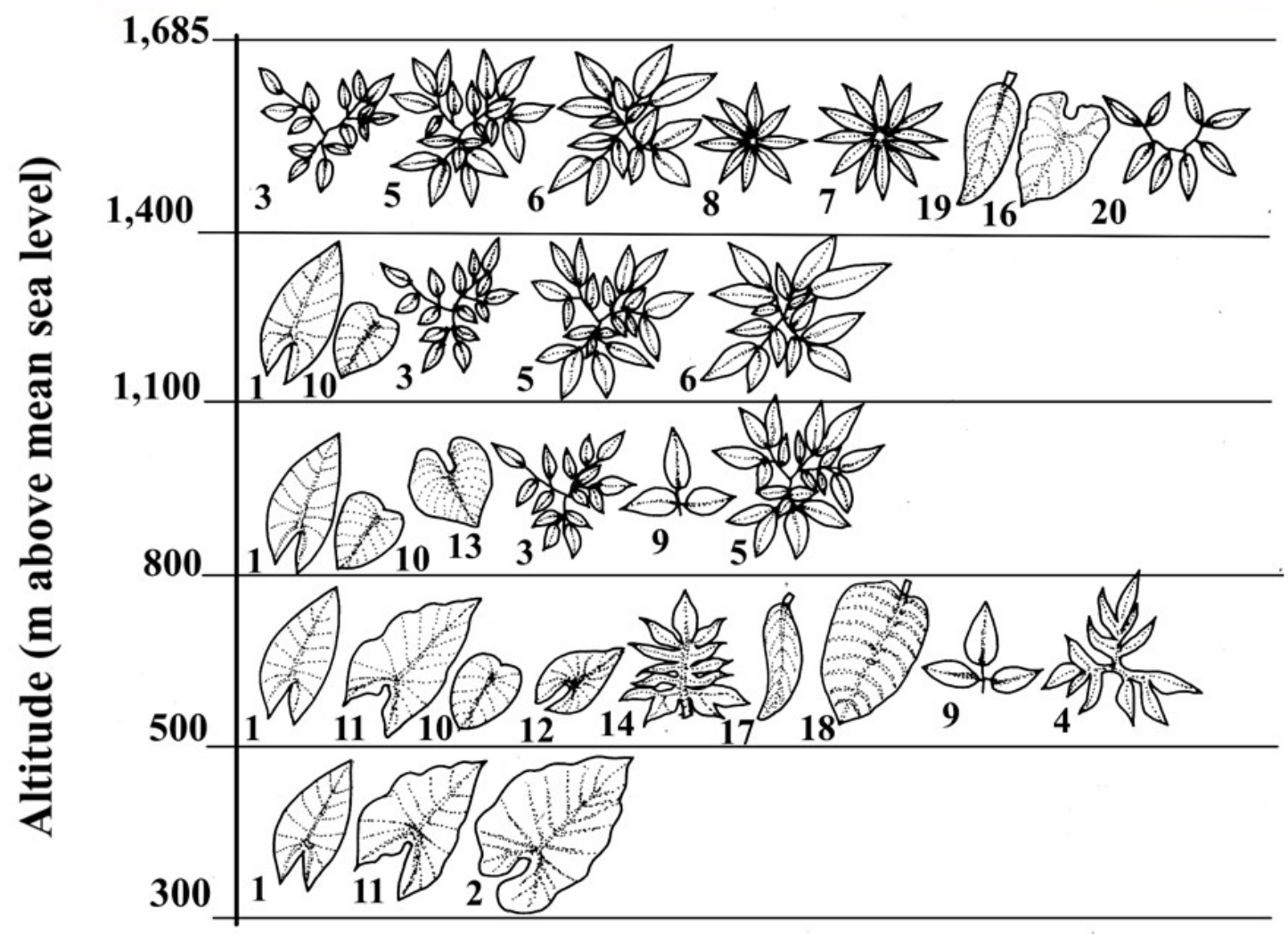

Fig. 3 Araceae species abundance along the altitudinal gradient, 300-1,685 m amsl in Doi Suthep-Pui National Park. Leaf shapes number 1-20 is in ascending order to 19 species (excepted Lemna sp. (15) did not show) in Table 1. 
At elevation 1,100-1,400 m amsl, five species were distributed in lower montane forest: A. acuminata, $A$. fuscus, A. thaiensis, A. yunnanensis and C. affinis. In this study plot, many hundreds individual numbers of dwarf taro or C. affinis were distributed densely around small basins under shade of wild banana bushes in the rainy season and disappeared in the winter and summer. A. acuminata grew well under shade of tree in this area, but Amorphophallus grew slowly and had low density. This might be that Alocasia could grow in less organic matter and dry soil, under low light intensity better than three species of Amorphophallus [13].

The lowest species number was at 300-500 m amsl, only four species in deciduous dipterocarp forest were found along the waterfall: $A$. acuminata, $A$. navicularis, C. esculenta and Lemna sp. However, Lemna sp. (Table 1 and Fig. 2), a tiny plant species, was discussed to alien species because this species had been found only once in small rock basin of the waterfall in February 2018 and had never been seen in other areas before. This hydrophyte species can easily invade, like the report of weed widespread quickly in alpine and subarctic mountain ecosystem by tourist trampling [27]. Thus, the illustration of Lemna sp. was not shown in Fig. 3. C. esculenta grew densely in this area and only four individual plants of $A$. navicularis were found in the river. This species was usually found at very high altitude more than 1,000 $\mathrm{m}$ amsl in lower montane forest, along the road or waterfall of Doi Su Thep and Doi Pui and also reported in Flora of Thailand (journal) [5]. It might be floated to this area by the flash flood and grew on soil in the bottom of waterfall.

Some Araceae species (A. consanguineum, Pothos scandens, $R$. decursiva, $R$. megaphylla, R. peepla and Scindapsus officinalis) are widely distributed ranging from the tropical Eastern Himalaya (Assam) through Northern Burma [28], while 11 species (A. yunnanensis, A. yunnanense, C. esculenta, L. spinosa, $P$. scandens, $R$. hookeriana, $R$. decursiva, $R$. megaphylla, R. peepla, S. hirsutum and S. horsfieldii) are reported in the Flora of China (journal) [29].

\subsection{Compared Species to Doi Inthanon National Park}

Aracies species study at Doi Inthanon National Park was recorded 23 species in 11 genera at $300-2,565 \mathrm{~m}$ amsl [13]. The results were shown and compared to this study at 300-1,685 m amsl (Table 2) because both national parks state on the different parts of Thanon Thong Chai Range and need to know about the same or different diversity and distribution. Eight species in Doi Suthep-Pui were not found in Doi Inthanon National Park: A. krausei, A. kerrii, A. maxwellii, C. affinis, $H$. benthamiana, $H$. aromatica, Lemna sp. and $R$. chevalieri, while 11 species were not found at Doi Suthep-Pui, although in the same elevation: $A$. macrorhizus, A. omkoiense, A. yunnanense var. yunnanense, C. fallax, P. scandens, Remusatia sp., $R$. decursiva, S. hirsutm, Sauromatum sp., S. officinalis and Typhonium roxburghii. The same species of both study sites were found in the same elevation. This result showed that the altitudinal zone was one of the main effects on the variation in Araceae species. Many researches reported about the effect of altitudinal gradients factor could determine the distribution of many plant families in Doi Inthanon National Park [30, 31] and Doi Suthep-Pui National Park [32, 33]. In South Korea on the ridge of the Baekdudaegan Mountains [34] and in China at Gauncen Mountain [35], the latitude and altitude had effects on plant species richness, diversity and community and different species were also found in Malaysia [36] and Brazil [37].

However, the difference of species distribution must be from other factors: light intensity, soil texture, soil $\mathrm{pH}$ and soil moisture content differed by forest type and forest subtype, deciduous or evergreen [32, 33, 38-40]. Relative humidity varied to season, water source and forest type liked the study of temperature, relative humidity and seasonal variability, especially monsoon on ambient air quality in a coastal urban area 
Table 2 Araceae species in Doi Suthep-Pui National Park at 300-1,685 m amsl in this study compared to Doi Inthanon National Park at elevation 300-2,565 m amsl [13].

\begin{tabular}{|c|c|c|c|c|}
\hline & Species & Life form & $\begin{array}{l}\text { Doi Suthep-Pui } \\
\text { elevation (m amsl) }\end{array}$ & $\begin{array}{l}\text { Doi Inthanon } \\
\text { elevation (m amsl) }\end{array}$ \\
\hline 1 & A. acuminata Schott & Geo & $300-1,400$ & $601-1,500$ \\
\hline 2 & $\begin{array}{l}\text { A. navicularis (K.Koch \& C.D.Bouché) K.Koch } \\
\text { \& C.D.Bouché }\end{array}$ & Geo & $300-500$ & $1,201-1,500$ \\
\hline 3 & A. fuscus Hett. & Geo & $801-1,685$ & $901-1,500$ \\
\hline 4 & A. krausei Engl. & Geo & $501-800$ & Not found \\
\hline 5 & A. macrorhizus Craib & Geo & Not found & $300-1,500$ \\
\hline 6 & A. thaiensis (S.Y.Hu) Hett. & Geo & $801-1,685$ & $601-1,500$ \\
\hline 7 & A. yunnanensis Engl. & Geo & $1,101-1,685$ & $601-1,500$ \\
\hline 8 & A. consanguineum Schott & Geo & $1,401-1,685$ & $901-2,565$ \\
\hline 9 & A. kerrii Craib & Geo & $1,401-1,685$ & Not found \\
\hline 10 & A. maxwellii Hett. \& Gusman & Geo & $501-1,100$ & Not found \\
\hline 11 & A. omkoiense Gusman & Geo & Not found & $1,501-1,800$ \\
\hline 12 & A yunnanense var. yunnanense Buchet & Geo & Not found & $1,501-1,800$ \\
\hline 13 & C. affinis Schott & Geo & $501-1,400$ & Not found \\
\hline 14 & C. esculenta (L.) Schott & Helo & $300-800$ & $300-1,500$ \\
\hline 15 & C. fallax Schott & Helo/Litho & Not found & $901-1,200$ \\
\hline 16 & H. benthamiana Schott & Geo & $501-800$ & Not found \\
\hline 17 & H. aromatica (Spreng.) Schott & Geo/Litho & $801-1,100$ & Not found \\
\hline 18 & L. spinosa (L.) Thwaites & Helo & $501-800$ & $300-600$ \\
\hline 19 & Lemna sp. & Hydro & $300-500$ & Not found \\
\hline 20 & Pothos scandens L. & Epi & Not found & $1,501-1,800$ \\
\hline 21 & R. hookeriana Schott & Epi & $1,401-1,685$ & $1,501-2,565$ \\
\hline 22 & Remusatia sp. & Litho & Not found & $901-1,200$ \\
\hline 23 & R. chevalieri Gagnep. & Epi/Litho & $501-800$ & Not found \\
\hline 24 & R. decursiva (Roxb.) Schott & Epi/Litho & Not found & $901-1,200$ \\
\hline 25 & R. megaphylla H.Li & Epi/Litho & $501-800$ & $601-900$ \\
\hline 26 & R. peepla (Roxb.) Schott & Epi/Litho & $1,401-1,685$ & $1,201-2,100$ \\
\hline 27 & S. hirsutum (S.Y.Hu) Cusimano \& Hett. & Geo & Not found & $901-1,500$ \\
\hline 28 & S. horsfieldii Miq. & Geo & $1,401-1,685$ & $1,201-1,500$ \\
\hline 29 & Sauromatum sp. & Geo & Not found & $1,201-1,500$ \\
\hline 30 & Scindapsus officinalis (Roxb.) Schott & Epi/Litho & Not found & $601-900$ \\
\hline 31 & Typhonium roxburghii Schott & Geo & Not found & $300-600$ \\
\hline
\end{tabular}

Geo = geophyte, Epi = epiphyte, Helo = helophyte, Hydro = hydrophyte, Litho = lithophyte, amsl = above mean sea level.

at North Chennai, India [41]. Topographic factors and soil properties are the main effects on diversity and distribution of Araceae in mountain ecosystems and might be response to climate change between 2000 and 2100, like the reported from China [42].

\subsection{Considering with Tourists Trample}

The results from the observation along these nature trails, vegetation abundance were changed by season and the altitude. Nevertheless, most of five nature trails could attract people to visit all year. The trample of tourists, riding bicycle and biking motorcycle to the highest peak along the road and the nature trails also affected Araceae abundance. Many species were found along the nature trails and main road, thus species can be harmed easily. In the rainy season, weeding by the park authority showed the disappearance of many Araceae in the habitat which were found in last year.

Carbon monoxide from cars and motorcycles in the city and national park is very high all year, especially in the winter season, there are many tourists in Chiang 
Mai Province and also in Doi Suthep-Pui National Park. Air pollution could harm trees, decrease vegetation growth and be the cause of vegetation death in the summer. The tourists with heavy load could harm vegetation, benthic animals and environment. The focus on the trial allocation and making environmental education must keep vegetation variation rather than limiting the tourists [43].

Although, Araceae in this protected area is not collected for utilization by local people and hill tribes, but these herbaceous plants could be harmed and might be lost from the habitat by flash flood, forest fire, sunlight, air pollution, drought, very high temperature and weeding along the nature trails. Then, diversity and ecology study are important for establishing the database, planning and managing sustainable conservation for Araceae and other families to the mission of mountain ecosystem [18].

\section{Conclusions}

Twenty species of 11 genera were found: Amorphophallus four species, Arisaema and Rhaphidophora three species each, Alocasia and Colocasia two species each and Hapaline, Homalomena, Lasia, Lemna, Remusatia and Sauromatum had only one species in each. The highest diversity was at 500-800 $\mathrm{m}$ amsl (nine species) in dry evergreen forest and 1,400-1,685 m amsl (eight species) in cloud forest, at $800-1,100 \mathrm{~m}$ amsl in dry evergreen forest and 1,100-1,400 m amsl in lower montane forest, seven species were found, the lowest was at $300-500 \mathrm{~m}$ amsl (four species) in deciduous dipterocarp forest along the waterfall. Species diversity in the rainy season was the highest (1.75), the top five dominant species were dwarf taro $(C$. affinis Schott), wild taro (C. esculenta (L.) Schott), A. fuscus Hett., A. acuminata Schott and A. thaiensis (S.Y.Hu) Hett. (IVI\% 61.54, 24.13, 17.12, 16.52 and 9.60, respectively). In dry season, the dominant species was wild taro. The environmental factors and altitude gradients showed the main effect on diversity and distribution. Araceae species at Doi Suthep-Pui are variable in genera (11) and species (20). This showed the results of habitat in mountain ecosystems which directly related to altitudinal level and forest type. Seasonal changes, especially rainfall forced the abundance of evergreen or deciduous species. In the rainy season, closing high biodiversity nature trail such as Doi Pui Summit nature trail can conserve terrestrial plant, seed, bulb and sucker of species to grow rapidly very well.

However, weeding and disaster all year still disturbed to Araceae species, plant collection for using or selling is also still the risk for many species. The National Parks, Wildlife and Plant Conservation should force strategies and policies for protection of species from habitat and sustainable use for local people by recording endemic Araceae species to the three appendices of classification and permit requirements of Thailand by CITES. The status of species should be evaluated by the abundance and distribution, especially threatened species to the IUCN Red List Categories for sustainable conservation.

\section{Acknowledgments}

The authors would like to thank the Faculty of Liberal Arts and Science, Kasetsart University, Kamphaeng Saen Campus, Nakhon Pathom Province for research funding, the research team and local people from Doi Suthep-Pui National Park, Chiang Mai Province, families and friends, all from Thailand.

\section{References}

[1] Sukumolnondha, T. 2005. Variety of Amorphophallus in Thailand. Department of Agriculture, Ministry of Agriculture and Cooperatives, Thailand.

[2] Kaset, T. L. 2016. “Amorphophallus Grew Easily, High Income, Used for Food and Medicine." Accessed October 10, 2018. https://www.chiangmainews.co.th/page/ archieves/531812.

[3] Edmonton Horticultural Society. 2017. "Introduction to the Arum Family by Lyndon Penner." Gardening for a Better World. Accessed January 2018. https:/edmontonhort.com/introduction-to-the-arum-famil y-by-lyndon-penner. 

Chiang Mai Province in Thailand

[4] Bangkok Herbarium. 2014. Botanical Reports of Siam (192201933). Botanical Research and Herbarium Group, Office of Plant Variety Protection, Department of Agriculture, Ministry of Agriculture and Cooperatives, Bangkok, Thailand.

[5] Boyce, P. C., Sookchaloem, D., Hetterscheid, W. L. A., Gusman, G., Jacobsen, N., Idei, Y., and Du, N. V. 2012. “Araceae." Flora of Thailand 11 (2): 101-325.

[6] CITES. 2012. "Convention on International Trade in Endangered Species of Wild Fauna and Flora." Accessed October 5, 2012. http//www.cites.org.

[7] ThailandPlant.com. 2018. "Araceae." Thailand Plant. Accessed September 10, 2012. http//www.thailandplant. com/AmorphophallusAroidCrinumBulbTropicalPlant-pro duct.php?Mainlistld=5\&plantSID=729ufcpeadam 4 ek 5 uq 81 fhsm73.

[8] Sungkajanttranon, O., Kongsanun, T., Nuchthongmuang, W., and Horadee, S. 2010. "Systematic Studies of Family Araceae in Chaleamrattanakosin National Park." In Proceedings of 48th Kasetsart University Annual Conference: Plants, March 3-5, 2010. Kasetsart University, Bangkok, Thailand, 73-81.

[9] Sungkajanttranon, O., Petchsri, S., Huayhongthong, C., and Sookchaloem, D. 2013. "Growth of Amorphophallus muelleri Blume Emerged from Bulbil of Petiole in Greenhouse Condition.” Thai J. For. 32: 60-70.

[10] Sookchaloem, D., Sungkajanttranon, O., Petchsri, S., Horadee, S., Huayhongthong, C., Vanapanich, A., and Wongsawaddiwattana, C. 2016. "Leaf Blade Anatomy Characteristics of the Genus Amorphophallus Blume ex Decne. in Thailand." Agri. Nat. Res. 50 (6): 437-44.

[11] Sungkajanttranon, O., Marod, D., Sungkaew, S., Petchsri, S., Thanompun, K., Horadee, S., Huayhongthong, C., Vanapanich, A., Wongsawaddiwattana, C., Charoensuepsakul, P., Dongkumfu, W., Kongsatree, K., and Peankonchong, A. 2017. "Araceae Species in National Parks of Kanchanaburi Province and Chiang Mai Province in Thailand." In Abstract of 17th Flora of Thailand Conference: Taxonomic Knowledge and a Sustainable Future, Krabi, Thailand, 77.

[12] Sungkajanttranon, O., and Sookchaloem, D. 2017. "Phenology Study of Arum Plant in Greenhouse Condition." Thai J. For. 36 (1): 47-57.

[13] Sungkajanttranon, O., Marod, D., and Thanompun, K. 2018. "Diversity and Distribution of Family Araceae in Doi Inthanon National Park, Chiang Mai Province.” Agri. Nat. Res. 52 (2): 125-31.

[14] National Park Thailand. 2018. "Doi Suthep-Pui National Park." Department of National Parks, Wildlife and Plant Conservation. Accessed July 14, 2018. http://park.dnp.go.th/visitor/nationparkshow.php?PTA_C ODE $=1024$.
[15] Thai National Park. 2018. "Doi Suthep-Pui National Park." Accessed July 14, 2018. https://www.thainationalparks.com/doi-suthep-pui-nation al-park.

[16] Yarnvut, A., Sungkaew, S., Hermhuk, S., Sunthornhao, P., and Onprom, S. 2016. "Plant Diversity and Utilization on Ethnobotany of Local People at Hmong Doi Pui Village in Doi Suthep-Pui National Park, Chiang Mai Province." Thai J. For. 35 (3): 136-46.

[17] Hotels.com. 2018. "Chiang Mai." Accessed September 3, 2018. http://www.chiangmai.bangkok.com/attractions/ doi-suthep.htm.

[18] International Union for Conservation of Nature and Natural Resources. 2018. "Mountain Ecosystems." Commission on Ecosystem Management. Accessed October 5, 2018. https://www.iucn.org/commissions /commossion-ecosystem-management/our-work/cems-sp ecialist-groups/mountain-ecosystems.

[19] International Union for Conservation of Nature and Natural Resources. 2017. The IUCN Red List of Threatened Species. Version 2014.3. Accessed June 7, 2017. http://www.iucnredlist.org.

[20] Chotpiseksit, T., Sungkajanttranon, O., Petchsri, S., Marod, D., and Kongsatree, K. 2017. "Species Diversity of Araceae at Doi Suthep-Pui National Park, Chiang Mai Province." In Proceedings the 11th Botanical Conference of Thailand: BCT11, Bangkok, Thailand, 166-72.

[21] Shannon, C. E., and Weaver, W. 1949. The Mathematical Theory of Communication. Illinois: University of Illinois Press.

[22] Whittaker, R. H. 1975. Communities and Ecosystems, 2nd ed., New York, NY: Macmillan.

[23] Parotta, J. A., Turnbull, J. W., and Jones, N. 1997. "Catalyzing Native Forest Regeneration on Degraded Tropical Lands.” For. Ecol. Manag. 99 (1-2): 1-7.

[24] Mayo, S. J., Bogner, J., and Boyce, P. C. 1997. The Genera of Araceae. Belgium: Continental Printings.

[25] Wikipedia. 2018. "Chiang Mai Province.” Accessed June 4, 2018. https://th.wikipedia.org/wiki/Chiang_Mai_ Province.

[26] Sahunalu, P. 2010. Relationship between Climatic Condition and Plant Community along the Altitudinal Gradients in Doi Inthanon National Park. Research Report Number BGJ4380025 Thai Research Fund. Accessed July 16, 2012. https://elibrary.trf.or.th /project_contentasp?PJID=BGJ4380025.

[27] Lembrechts, J. J., Milbau, A., and Nijs, I. 2014. "Alien Roadside Species More Easily Invade Alpine than Lowland Plant Communities in a Subarctic Mountain Ecosystem." PLOS ONE 9 (6): e102109. Accessed July 14, 2018. http://journals.plos.org/plosone/ article?d=10.1371.journal.pone.0089664. 
[28] Boyce, P. C. 2009. "Ariopsis (Araceae: Colocasieae) a New Generic Record for Thailand \& Preliminary Observation on Trans Himalayan Biogeography in Araceae." Thai. For. Bull. (Bot.) 37: 9-14.

[29] Li, H., Zhu, G., Boyce, P. C., Murata, J., Hetterscheid, W. L. A., Bogner, J., and Jacobsen, N. 2010. "Araceae." Flora of China 23: 3-79. Accessed July 26, 2018. http://www.efloras.org/florataxon.aspx?flora_id=2\&taxon $\mathrm{id}=10056$.

[30] Sungpalee, W. 2002. "Some Ecological Characteristics of Deciduous Forests along the Altitude Gradients in Doi Inthanon National Park.” M.S. thesis, Kasetsart University.

[31] Teejuntuk, S., Sahunalu, P., Sakurai, K., and Sungpalee, W. 2003. "Forest Structure and Tree Species Diversity along an Altitude Gradient in Doi Inthanon National Park, Northern Thailand." Tropics 12 (2): 85-102.

[32] Marod, D., Sangkaew, S., Panmongkal, A., and Jingjai, A. 2014. "Influences of Environmental Factors on Tree Distribution of Lower Montane Evergreen Forest at Doi Suthep-Pui National Park, Chiang Mai Province." Thai J. For. 33 (3): 23-33.

[33] Marod, D., Hermhuk, S., Jingjai, A., Thinkamphaeng, S., and Panmongkol, A. 2015. "Tree Distribution across the Forest Ecotone of Lower Montane Forest at Doi Suthep-Pui National Park, Chiang Mai Province.” Thai J. For. 34 (3): 99-108.

[34] Lee, C., Chun, J., Cho, H., and Song, H. 2012. "Altitudinal Patterns of Plant Species Richness on the Ridge of the Baekdudaegan Mountains, South Korea: Area and Mid-domain Effect." For. Sci. Tech. 8 (3): 154-60.

[35] Xu, M., Ma, L., Jia, Y., and Lui, M. 2017. "Integrating the Effects of Latitude and Altitude on Spatial Differentiation of Plant Community Diversity in a Mountainous Ecosystem in China." PLOS ONE 12 (3): e0176866. Accessed August 12, 2018. https://www.ncbi.nlm.nih.gov/pmc/articles/PMC5360330/.
[36] Mansor, M., Boyce, P. C., Othman, A. S., and Sulaiman, B. 2012. "The Araceae of Peninsular Malaysia." Penerbit Universiti Sains Malaysia, Pulau Pinang, Malaysia.

[37] Andrade, I. M., Mayo, S. J., Silva, M. F. S., de Sousa, D. J. L., Matias, L. Q., and Ribeiro, T. A. 2013. "The Araceae in Ceará, Brazil: Humid Forest Plants in a Semi-Arid Region.” Rodriguesia 64 (3): 445-77.

[38] Santisuk, T. 2007. Forest of Thailand. Department of National Parks, Wildlife and Plant Conservation, Bangkok, Thailand.

[39] Wang, J., Wang, H., Cao, Y., Bai, Z., and Quin, Q. 2016. "Effect of Soil and Topographic Factors on Vegetation and Restoration in Open Cast Coal Mine Dumps Located in a Loess Area." Scientific Reports 6: 1-11. Accessed June 23, 2018. https://www.nature.com/articles/ srep22058.

[40] Saikammoon, R., Thinkampaeng, S., and Marod, D. 2018. "Stand Clustering and Ordination Based Determined Factors in Sakerat Man and Biosphere Reserve, Nakhon Ratchasima Province." In Proceeding of Forestry Conference in 2018: National Forest Reform, August 22-24, 2018, Bangkok, Thailand, 1-86.

[41] Jayamurugan, R., Kumaravel, B., Palanivelraja, S., and Chockalingam, M. P. 2013. "Influence of Temperature, Relative Humidity and Seasonal Variability on Ambient Air Quality in a Coastal Urban Area." Inter. J. Atmos. Sci. 13: 1-7.

[42] Jiang, Y., Zhuang, Q., Schaphoff, S., Sitch, S., Skolov, A., Kicklighter, D., and Melillo, J. 2012. "Uncertainty Analysis of Vegetation Distribution in the Northern High Latitudes during the 21st Country with a Dynamic Vegetation Model.” Ecol. Evol. 2 (3): 593-614.

[43] Janokova, J., Koscova, M., and Jablonska. J. 2015. "Tourism Load and Possibilities for Reducing the Environmental Impacts: Case Study at the Slovak Paradise National Park (Slovakia)." Ekologia 34 (3): 281-92. 